\title{
Technique et culture chez les chimpanzés sauvages
}

\section{Christophe Boech et Hedwige Boesch-Achermann}

\section{(2) OpenEdition}

Journals

Édition électronique

URL : https://journals.openedition.org/tc/547

DOI : $10.4000 /$ tc. 547

ISSN : 1952-420X

\section{Éditeur}

Éditions de l'EHESS

\section{Édition imprimée}

Date de publication : 1 novembre 1995

ISSN : 0248-6016

\section{Référence électronique}

Christophe Boech et Hedwige Boesch-Achermann, «Technique et culture chez les chimpanzés sauvages », Techniques \& Culture [En ligne], 23-24 | 1995, mis en ligne le 07 décembre 2005, consulté le 29 septembre 2022. URL : http://journals.openedition.org/tc/547 ; DOI : https://doi.org/10.4000/tc. 547

Ce document a été généré automatiquement le 29 septembre 2022.

Tous droits réservés 


\section{Technique et culture chez les chimpanzés sauvages}

Christophe Boech et Hedwige Boesch-Achermann 